\title{
Theoretical Study of Photovoltaic Thermal Integrated Absorption Cooling System under Jordan Climate
}

\author{
Mohammed Al-Odat*" ${ }^{1}$, Mohamad Okour ${ }^{1}$, Ahmed Dawahed ${ }^{2}$, Isam Qasem ${ }^{1}$, Fayez Elessa ${ }^{1}$

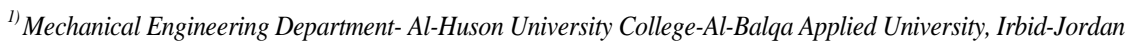 \\ ${ }^{2)}$ Mechanical Engineering Department- Jordan University of Science and Technology Irbid-Jordan
}

This paper presents a theoretical investigation to simulate the utilization of (PV/T) technology to drive an absorption refrigeration system that is used for air conditioning of a classroom under Jordan climate conditions. The absorption refrigeration cycle u ses the hot water from the PV/T collector with an assisted electrical heater as a heat source in the generator. In addition to the capability to utilize the PV/T to supply the building by domestic hot water and electricity if no need to run the refrigeration cycle. This analysis was carried using excel program and theoretical equations for the system. It was found that (PV/T) technology is very useful for thermal applications with high efficiency. Also, absorption refrigeration cycle has a good coefficient of performance because it mainly depends on the thermal energy with low electrical energy consumption to run the pump. Moreover, this system has a short payback period, low energy consumption, low running cost, and minimum environmental impact. The results of this study show that the system needs about ( $84 \mathrm{~m}^{2} \mathrm{PV} / \mathrm{T}$ collectors) to cover 16 tons cooling load.

Keywords: Solar radiation, PV/T cell, thermal efficiency, electrical efficiency, absorption refrigeration, numerical solution

\section{Introduction}

Energy production, efficient use for energy and environmental impact become one of the main problems in the world; developing different renewable energy recourses (such as solar energy, wind energy, hydraulic energy ...etc.) can contribute to overcome these problems. Solar energy is one of the most important renewable energy resources due to its large amount and its availability. Solar energy, in general, can be utilized in two methods: first, the solar thermal power that can be employed as heating energy by different types of solar thermal collectors that convert solar thermal energy to thermal heat. Second, converting the solar light energy directly to electricity using solar photovoltaic technology. This research work addresses a new technology called thermal photovoltaic collector which is a cumulative technology between photovoltaic modules and solar thermal collectors (Bhargava $e t$. al. 1993). Thermal photovoltaic (PV/T) collectors is a new technology which used to utilizing the solar thermal and electrical energy simultaneously, this system depends on single crystal solar cells to convert solar light to produce electricity and embedded solar collector in the module used to absorb solar thermal heat energy from solar radiation by transfer the heat from absorption plat to working fluid in collector, also the working fluid in collector will make a good role to cool the cells which leads to increase the efficiency of the solar module. New PV technology developed in the last decade like organic PV cells, fixable PV (Pagliaro et. al. 2008). The thermal PV system is classified according to the PV/T design and cooling liquid PV/T collector, air $\mathrm{PV} / \mathrm{T}$ collector and concentrated PV/T collector (Tyagia et. al 2012). Concentrating photovoltaic technology is one of the fastestgrowing solar energy technologies, electrical conversion efficiency can reach more than $43 \%$. The operating temperature of a solar cell strongly influences the performance of a photovoltaic system reducing its efficiency with a negative temperature coefficient. Thus, cooling systems represent a very important aspect in photovoltaic applications (Micheli et. al 2013, Brinkworth and M. Sandberg 2006). Many applications are developed to utilize the PV/T such as employing the generated hot water from collector for cooling in the absorption system (Gur Mittelman et. al 2007) or direct utilization as a domestic hot water (Vokas et. al 2006). In addition, PV/T can be used in the water desalination systems (Mittelman2009, Kumar and Tiwari 2008). The air PV/T type can be utilized to preheat the ventilating air (Twinsolar 2010) or for space heating (Ji J, et al 2009), also some research was tried to use the air PV/T for crop drying (Tiwari et. al. 2009) and marine drying (Fudholi et al 2010). A new idea for using the PV/T in hydrogen production is reported by Ratlamwalam (2011). Absorption refrigeration cycle is system generally consist of two evacuated containers: the first one contains a liquefied refrigerant which will be used in the refrigeration cycle. The second one contains the absorption liquid, this liquid will absorb the refrigerant liquid until reach saturation, and then this homogeneous solution will be pumped. The solubility of absorption liquid in refrigerant fluid will be reduced by heating. Fin ally, the produced refrigerant will be taken to complete the ordinary refrigeration cycle (Assilzadehet al 2005). Thus the system depends on the thermal heat energy supplied by the thermal photovoltaic collector using a water as a cooling fluid for the cell, and an auxiliary heater can be used to increase the water temperature to the obtain an optimum cycle performance. Also, this system can be used for lighting when there is no need to drive the refrigeration cycle.

Received on March 27, 2019; accepted on October 1, 2019 Correspondence concerning this article should be addressed to Mohammed Al-Odat (E-mail address: m.odat@bau.edu.jo).ORCiD ID of Mohammed Al-Odat https://orcid.org/0000-0002-2877-1611 
The system has many advantages such as supplying the building with domestic hot water and electricity and the system can be grid-connected if the electricity generated by the PV/T more than the building demands. Dai et. al. (2017) studied numerically a hybrid photovoltaic solar-assisted loop heat pipe/heat pump (PV-SALHP/HP) water heater system. Their system was a combination of loop heat pipe (LHP) mode and heat pump (HP) mode, and the two modes can be run separately or compositely according to the weather conditions. Recently, Dubey and Supinator (2018) analyzed a novel integrated solar photovoltaicthermal-refrigeration (PVTR) system used to produce hot water and air-conditioning in the tropical climate conditions of Singapore. They formulate a dynamic simulation model for the analysis of the PV sandwich attached with a solar flat plate collector and for the main components of the refrigeration system. Most recently Ammar et. al. (2019) reported the energy and energy performance of a photovoltaic/thermal solar-assisted heat pump system (PV/TSAHPS) with different solar radiation levels. From the heat pump, the solar evaporator/collector extracts the thermal energy required, while the cooling effect of the refrigerant reduces the working temperature of the PV cells. The previous literature review shows that the application of this particular PV/T system for absorption refrigeration under Jordan climate conditions has not been investigated yet. This was the motivation of the present work. This study focus on cooling of classroom in Jordan University of Science and Technology by operating a single effect absorption refrigeration system with lithium bromide as a working fluid. This system needs a heat source to drive the refrigeration cycle. Thus a flat plat thermal photovoltaic collector PV/T is used to supply the absorption cycle by required heat to drive the cycle under Jordan climate. This work introduces a case study on the cooling a classroom in Jordan University of Science and Technology using proposed techniques along with an economic analysis and payback period calculations.

\section{Materials and Methodology}

An absorption cooling system was designed for cooling, this cooling absorption system needs a heat source to drive the refrigeration system. In this work, the heat source is supplied by a hot water stored in a storage tank connected to the output of the thermal flat plate of the PV/T system. The hot water is overheated by an auxiliary electrical heater that inserted in the storage tank to obtain the required temperature to drive the cycle efficiently as shown in Figure 1.

\subsection{Thermal photovoltaic collector}

Thermal photovoltaic collector is a new technology that can generate electricity from the solar cells in addition to hot water from thermal flat plate collector attached to the bottom of the PV cells, the thermal energy is generated from the solar radiation and from cooling of the PV cells (Tyagia et. al. 2012). It was found that cooling the PV cells leads to increase electrical efficiency (Ibrahim et. al. 2011). A water PV/T collector type used in this work is illustrated in Fig. 1. A PV/T analysis generally is a combined between a thermal flat plate collector and PV panel so a thermal and electrical analysis will be carried out for the PV/T system under consideration.

\subsubsection{Thermal analysis}

The Reynolds and Nusselt number are given in equations (1) and (2) (Cengel et. al. 2011)

$$
\begin{aligned}
& R e=\frac{\rho v D}{\mu} \\
& N u=0.664 \operatorname{Re}^{1 / 2} \operatorname{Pr}^{1 / 3}
\end{aligned}
$$

A heat transfer analysis is done for the thermal part of system molding and this is given by the following equations (Duffie and William 2013)

Thermal efficiency is given by equation (3)
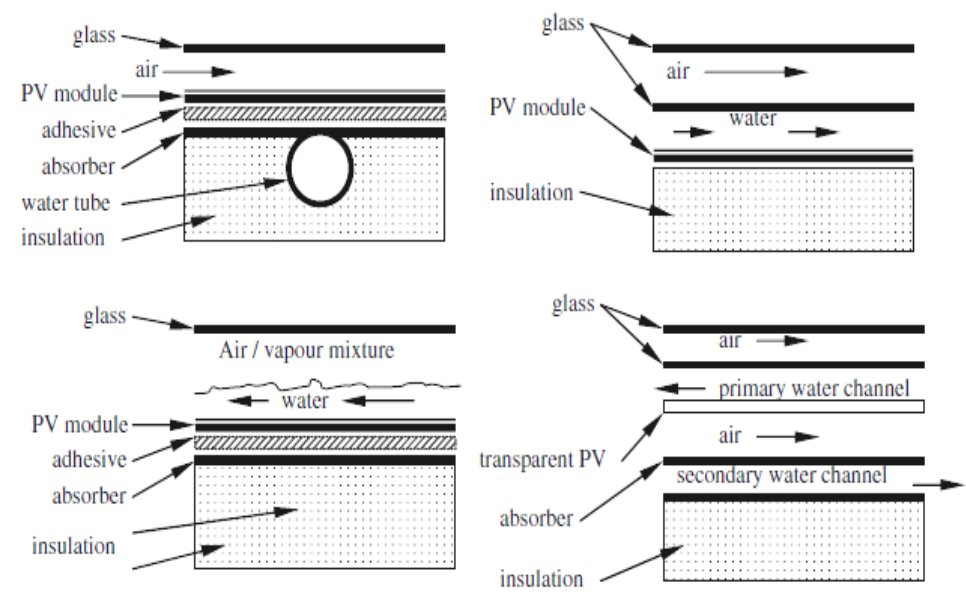

Fig. 1 Water-type PV/T cell.

$\eta t h=\frac{Q u}{G A C}$ 
The heat transfer coefficient of the heat losses from glass cover to the ambient $h c, p_{c}$ is given by equation (4) which depends on Re and $\mathrm{Nu}$.

$h c, p_{c}=h w=\frac{N u \cdot D}{k}$

The heat transfer coefficient for radiation heat loss from glass to the ambient hr,c_a is given in equation (5)

$h r, c_{a}=\epsilon g \sigma(T p+T a)\left(T p^{2}+T a^{2}\right)$

And the heat transfer coefficient from plat to the glass hr,p_c is represented in equation (6)

$h r, p_{-} c=\frac{\sigma(T p+T a)\left(T p^{2}+T a^{2}\right)}{\frac{1}{\varepsilon r}+\frac{1}{\varepsilon p}-1}$

So the overall heat transfer coefficient $\mathrm{Ul}$ is calculated by equation (7)

$U l=\left(\frac{1}{\left(h c, p_{c}+h r, p_{c}\right)}+\frac{1}{\left(h w+h r, c_{a}\right)}\right)^{-1}$

And collector efficiency factor $F^{\prime}$ is given by equation (8)

$F^{\prime}=\frac{1 / U l}{W\left[\frac{1}{U l[D o(W-D o) F]}+\frac{1}{c b}+\frac{1}{\pi D i h f i}\right.}$

Where

$c b=\frac{k b}{\delta}$

In equation (10) issued to fiend FR.

$F R=\frac{\dot{\mathrm{m}} c p}{A c U l}\left[1-\exp \left(-\frac{U l F^{\prime} A c}{\dot{\mathrm{m}} c p}\right)\right]$

The fin efficiency factor $F$ is calculated by equation (11)

$F=\frac{\tanh (x)}{x}$

Where $\mathrm{x}$ equal to

$x=\sqrt{\frac{U l}{k \delta}\left(\frac{W-D o}{2}\right)}$

$D o=D i+t$

For the heat transfer analysis for the plate collector to calculate the net heat gain by the collector $Q u$ in equations (14) and (15)

$Q u=\operatorname{AcFr}[S-U l(T i-T a)]$

$Q u=\dot{\mathrm{m}} c p(T o-T i)$

\subsubsection{PV panel analysis}

The electrical analysis is done for the PV/T panel firstly the electrical efficiency is given by equation (16)

$\eta_{e l}=\eta_{o}(1-\beta[T-25])$

And the cell PV panel temperature correlation is given by equation (17) (Lasnier and Ang, 1990). 
$T_{p v}=30.0006+0.0175(G-300)+1.14\left(T_{a}-25\right)$

\subsection{Absorption cycle}

The working fluid in the absorption refrigeration cycle is a binary solution consisting of a refrigerant and an absorbent. A survey of absorption fluids provided by Marcriss suggests that there are some 40 refrigerant compounds and 200 absorbent compounds available cycle (Srikhirinet al. 2001). For the single effect absorption cycle Fig. (2), there are different input parameters (such as $\mathrm{T}_{\mathrm{g}}, \mathrm{Tc}, \mathrm{Ta}, \mathrm{Te}, \mathrm{EL}, \mathrm{Q}_{\mathrm{E}}$ ) that must be known in order to determine the thermodynamic properties at each stage in the cycle and amount of heat and mass flow rate in each component. The absorption cycle modeling depends on the thermodynamic and fluid analysis is given by the following equations (Srikhirin and Aphornratana, 2001).

Firstly, a Conservation of mass where the total mass input equal to the total mass output for each control volume in the system.

$\Sigma \dot{m i}=\Sigma \dot{m o}$

Conservation of energy where the total amount of energy input without energy generation equal to the total amount of energy output for each control volume in the system

Qin $+\Sigma \dot{m i} . h i=\Sigma \dot{m o n} \cdot h o+$ Wout

Conservation of species where the total mass multiplied by the concentration input equal to the total mass multiplied by the concentration output for each control volume in the system.

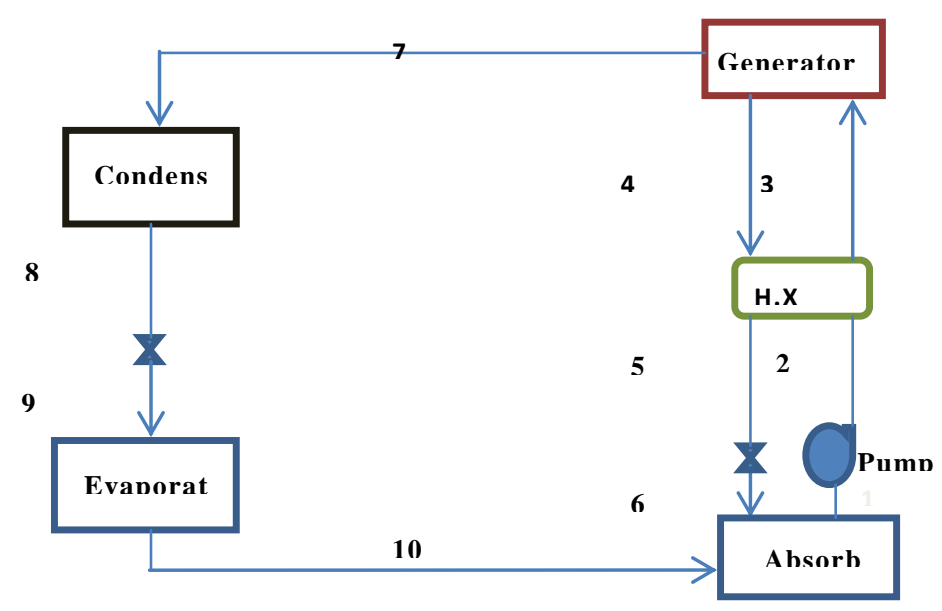

Fig. 2 Schematic diagram of single-effect absorption cycle

$$
\Sigma \dot{m i} . X i=\Sigma \dot{m o X o}
$$

Coefficient of performance of the cycle equal ratio of the evaporator energy to the generator energy and pump work

$$
\mathrm{Cop}=\frac{Q e}{Q g+W p}
$$

\subsection{System integration}

The system integration is done by transfer the hot water from the flat plate PV/T to the storage tank and then increase the water temperature by an auxiliary heater driven by the PV/T panel electrical energy as shown in Figure 3.

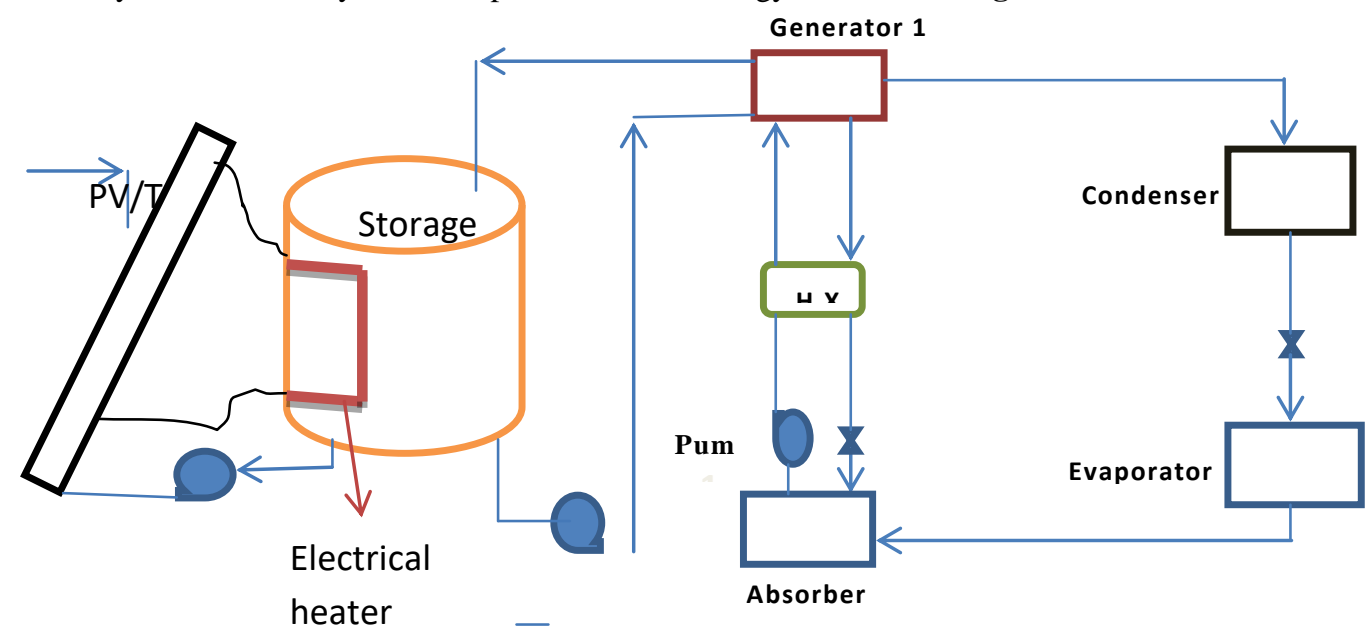

Fig. 3 Schematic diagram of the system 


\subsection{Simulation parameters}

The simulation parameters are listed in Table 1. Numerous parameters that affect the system performance were investigated these parameters are wind speed, ambient temperature, generator and condenser temperatures, and the water mass flow rate.

\section{Results and Discussion}

\subsection{Solar radiation}

The simulation has been carried utilizing MS Excel to solve the equations and investigate the effect of the variables mentioned in the above section. Figure 4 shows the variation of the measured solar for Irbid city in Jordan, this data was obtained from the energy center in Jordan University of Science and technology by a Pyranometer device. Figure 4 shows a normal distribution of solar radiation during the day in months from June to September, but there is a slight variation in the solar radiation in May and October. The slight variation of the solar radiation in May and October is due to the presence of some clouds that shaded the solar radiation from the Pyranometer.
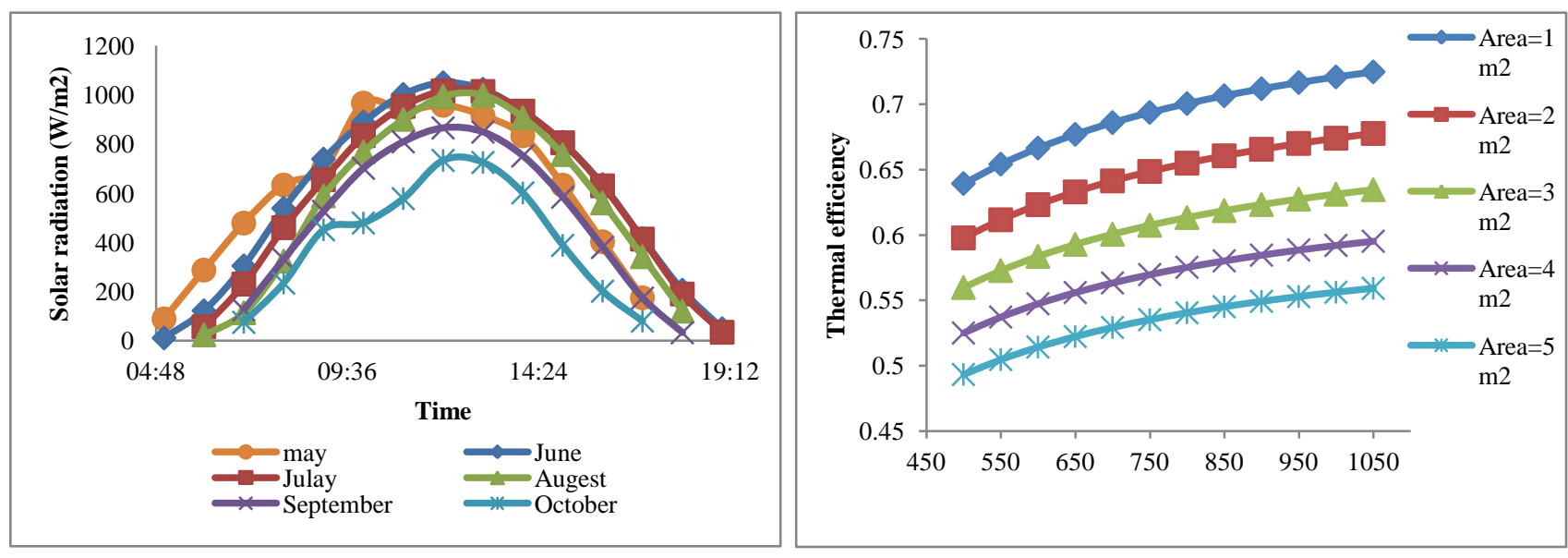

Fig. 4 Measured solar radiation in Irbid-Jordan for different months
Table 1 Simulation input parameters

\begin{tabular}{ll}
\hline Parameter & Value \\
Flat plate width(W) & $0.5 \mathrm{~m}$ \\
Water inlet temperature(Ti) & $55^{\circ} \mathrm{C}$ \\
Emissivity of the glass $(\varepsilon \mathrm{c})$ & 0.88 \\
Emissivity of the plate( $(\mathrm{p})$ & 0.95 \\
Fin thickness $(\delta)$ & $0.5 \mathrm{~mm}$ \\
Inner diameter of the tube (Di) & $10 \mathrm{~mm}$ \\
Outer diameter of the tube (Do) & $12 \mathrm{~mm}$ \\
Tube spacing (w) & $150 \mathrm{~mm}$ \\
Bond width(b) & $2 \mathrm{~m}$ \\
Fin thermal conductivity(k) & $385 \mathrm{~W} / \mathrm{m} . \mathrm{k}$ \\
$\quad$ For the absorption cycle: & $7\left({ }^{\circ} \mathrm{C}\right)$ \\
Evaporator temperature(Te) & $40\left({ }^{\circ} \mathrm{C}\right)$ \\
Absorber temperature(Ta) & 0.8 \\
Heat exchanger efficiency & 16 ton \\
Cooling load & \\
\hline
\end{tabular}

Fig. 5 Solar radiation effect on thermal efficiency of PV/T for various areas (Area is in $\mathrm{m}^{2}$ )

\subsection{PV/T Performance Results}

A thermal and electrical analysis was carried out for the PV/T collector, this analysis takes into consideration all the major parameters that affect the system performance. Figure $\mathbf{5}$ shows the results of studying the effect of solar radiation intensity and the collector area on the thermal efficiency of the PV/T collector. It can be seen that the thermal efficiency of the PV/T increases as the solar radiation increases; this is due to an increase of the amount of input solar power to the collector which leads to an increase in its efficiency. In addition to is clear that the thermal efficiency of the PV/T collector increases by decreasing the collector area, this behavior can be attributed to the increase of the heat loss to the ambient with the increase in the area. Figure 6 shows the effect of the wind speed on the thermal efficiency of the PV/T collector for various areas. It is obvious that as the wind speed increases the thermal efficiency of the PV/T decreases. This trend is attributed to the increase of the heat loss by the increase in the wind velocity due to the increase of the heat transfer coefficient hc,p_c between the plate and the ambient. The influence of the water mass flow rate on the thermal performance of the PV/T collector is displayed in Figure 7. It obvious that 
the thermal efficiency of the PV/T increases as water flow rate increases until a specified flow rate, then the efficiency remains constant. This study was done for various areas and all show a similar trend, firstly as the mass flow rate increase that means an increase in the heat gain from the absorber to the water but after a specific value of mass flow rate, an increase in the mass flow rate doesn't affect the thermal efficiency.

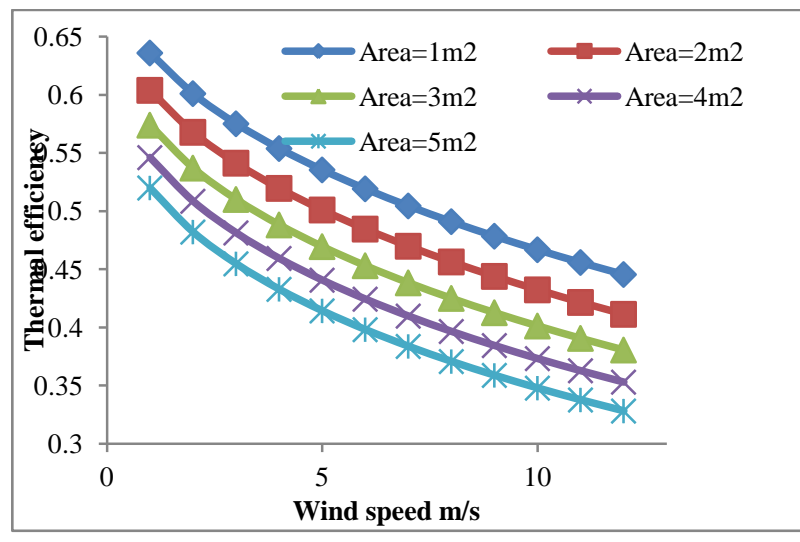

Fig. 6 Wind speed effect on the thermal efficiency of the PV/T for various areas (Area is in $\mathrm{m}^{2}$ )

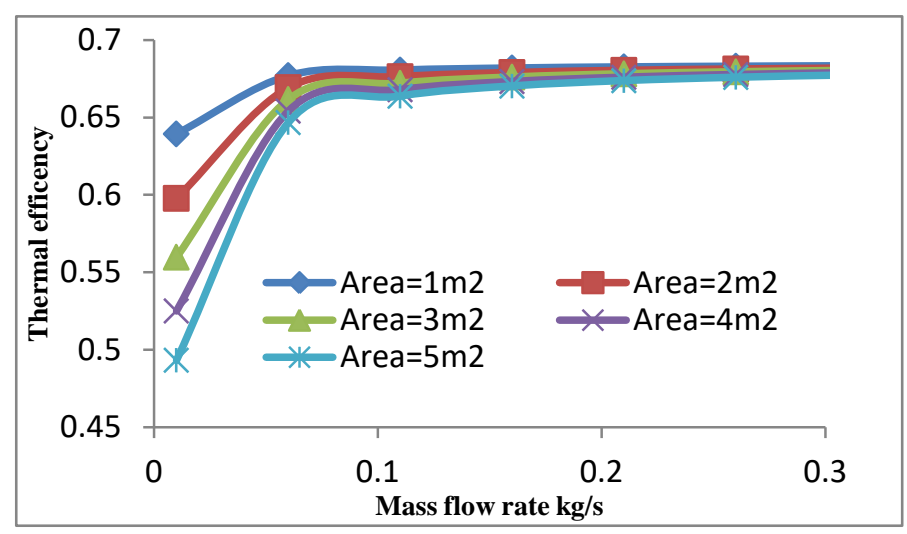

Fig. 7 Mass flow rate effect on the thermal efficiency of the PV/T for various areas (Area is in $\mathrm{m}^{2}$ ).

The electrical efficiency of the PV/T cell is investigated taking into account the main parameter that affects PV cells efficiency which is the cell. Figure 8 shows the influence of the cell temperature on the PV/T cell's electrical efficiency. As shown in Figure 8 an increase in the PV/T cells temperature leads to a decrease i the electrical efficiency of the PV/T cells during a day. This behavior is similar to the results reported by Swapnil and Dubey(2018). The total energy gain by the PV/T during the month of June solar radiation during the daytime for various ambient temperature is displayed in Figure 9. It can be seen that the energy generated by the PV/T increases as the solar radiation increases during the day. Although the PV/T cells efficiency decreases as the ambient temperature increases but the increase of the ambient temperature leads to the decrease of the thermal loss to the ambient which in turns increases the thermal efficiency, therefore, the total energy increases.

\subsection{Absorption cycle}

A numerical analysis was carried for the absorption refrigeration cycle. The effect of the generator temperature on the generator energy at different condenser temperature is shown in Figure 10. It can be seen that, as the generator temperature increases the generator energy decrease at the beginning due to increasing the coefficient of performance (COP). Continuing to increase in the generator temperature leads to the decrease of the COP so the generator temperature increase. Also as the condenser temperature increases the generator energy increases, because the increase in condenser temperature leads to reduce the amount of heat rejection from the condenser.
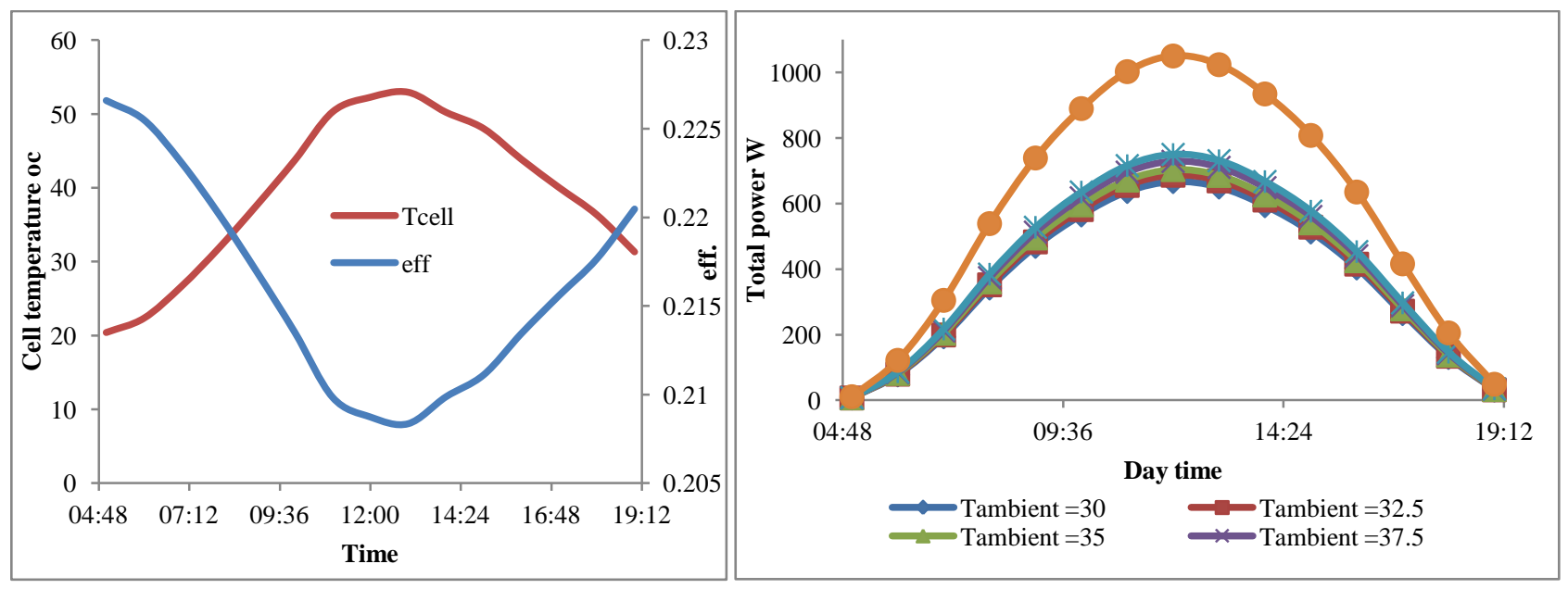
Fig. 8 The PV/T cells temperature and the effect of this temperature on the electrical efficiency
Fig. 9 The total power output from the PV/T for June month during the day. $\mathrm{T}$ ambient is in $\left({ }^{0} \mathrm{C}\right)$

The effect of generator temperature on the COP of the absorption cycle at various condenser temperatures is shown in Figure $\mathbf{1 1}$. It clear that COP increases initially then a decrease occur as the generator temperature increase for various condenser temperature. There is an optimum generator temperature which depends on the value of the condenser temperature and this behavior is consistency with results reported by Kaushik and Arora, (2009). This can be explained by the fact that as the generator temperature increases the amount of refrigerant generated increases and this, in turn, leads to improve the COP. Although an increase in the generator temperature leads to an increase in the amount of refrigerant generated but an extra increase in generator temperature leads to an increase of the refrigerant temperature and thus reducing the COP. Also as shown when the condenser temperature increases the COP decreases this is due to the decrease of the heat rejected by the condenser.

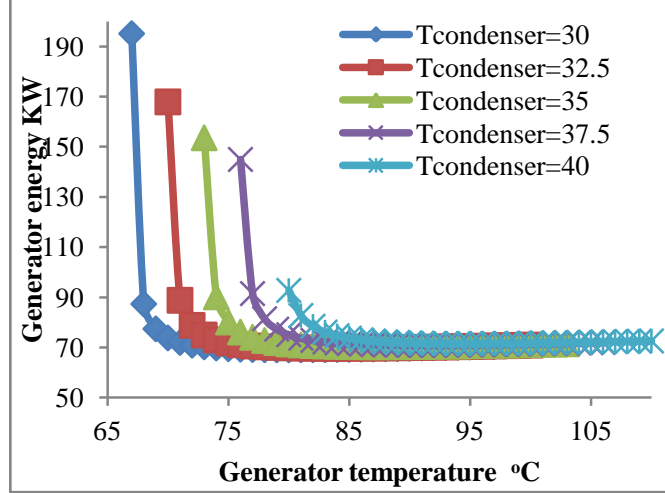

Fig. 10 The effect of generator temperature on the generator energy of the absorption cycle for various condenser temperatures (T ambient is in $\left({ }^{0} \mathrm{C}\right)$ ).

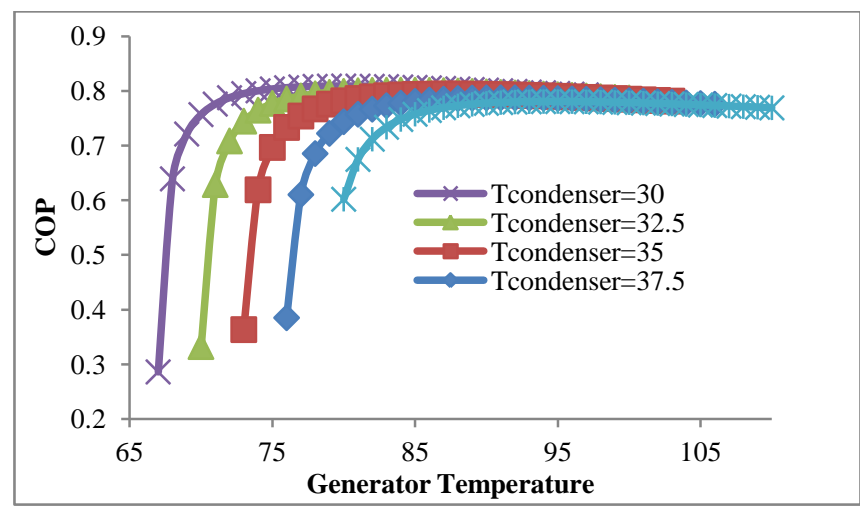

Fig. 11 The effect of generator temperature on the COP of the absorption cycle for various condenser temperatures $\left(\mathrm{T}_{\text {ambient }}\right.$ is in $\left.\left({ }^{0} \mathrm{C}\right)\right)$

Figure 12 represents the influence of the generator temperature on the water flow rate at various condenser temperature. It can be seen that as the generator temperature increases the needed water flow rate decreases, due to the increase of the amount of heat supplied by the water. In addition to the increase in the condenser, temperature leads to an increase in the water flow rate needed.

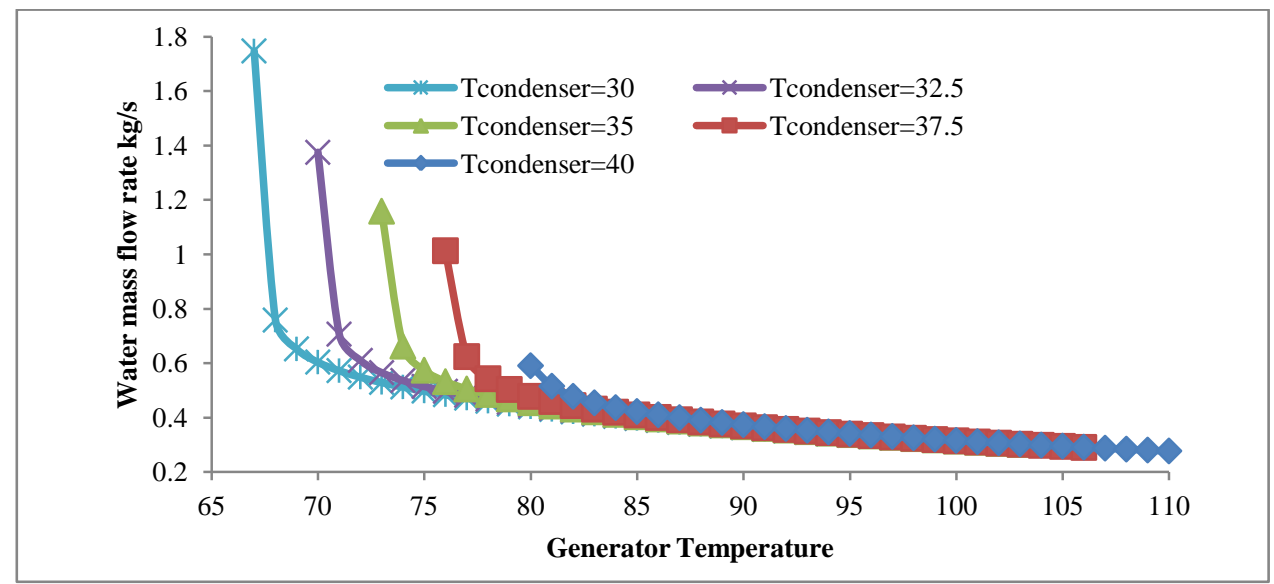

Fig. 12 The effect of generator temperature on the water flow rate of the absorption cycle for various condenser temperatures $\left(\mathrm{T}_{\text {ambient }}\right.$ is in $\left.\left({ }^{0} \mathrm{C}\right)\right)$.

\section{Case Study and Economical Analysis}

The selected parameters that affect the performance of the cycle, are generator temperature, mass flow rate, and the number of collectors. Now to select the values of these parameters the conditions which the cycle runs on it should be known, to get the best performance and reduce the number of thermal photovoltaic modules to run this cycle. So if the system operated at an ambient temperature of $31^{\circ} \mathrm{C}$, then the cycle should be operated at generator temperature $\mathrm{Tg}=80^{\circ} \mathrm{C}$ because if the system runs at this 
generator temperature this will get the optimum performance of the cycle and will get the maximum COP of the cycle. Moreover at any other ambient temperature the system subjected to a slight decrease in the COP. At the optimum generator temperature, the $\mathrm{PV} / \mathrm{T}$ collector generates about $170 \mathrm{~W}$ electricity and 500W thermal power. The Average ambient conditions throughout the year in Irbid city is depicted in Table 2.

Table 2 Average ambient conditions throughout the year in Irbid city (Jordan Meteorological Department, 2016).

\begin{tabular}{llllllllllll}
\hline Month & 1 & 2 & 3 & 4 & 5 & 6 & 7 & 8 & 9 & 10 & 11 \\
\\
\end{tabular}

\subsection{Cost analysis}

The cost analysis for the system at hand include the cost of the PV/T collectors and the cost of the absorption chiller. The economical investigation is presented in the following sections.

\subsubsection{PV/T cost}

The PV/T cost analysis was done by Tomas Matuska (2014) where the cost of the PV/T is $290-410 € / \mathrm{m}^{2}$ for nonselective type and $370-500 € / \mathrm{m}^{2}$ for selective type PV/T solar collectors. In this research work, these values will be considered.

\subsubsection{Absorption chiller cost}

Absorption chiller cost was represented by the chiller cost, auxiliary cost, and maintenance cost this cost was correlated by Brown (2002) these correlations are represented in equations (22-24). The electricity for the absorption chiller and the condenser pumps, water pumps, and cooling tower fans will be supplied from the PV/T collector's electrical energy. The result of economic analysis as per the above assumptions are presented in Table $\mathbf{3}$.

Installed cost, $\$=1,819.4 \times T R^{0.8452}$

Annual O\&M = $20 \times$ TR

Auxiliary electricity consumption $=0.14 \mathrm{KW} / \mathrm{TR}$

In summary, the system should be operated on a certain optimum parameters that yield the optimum performance. These optimum specific conditions are as follows: generator temperature $\mathrm{TG}=80{ }^{\circ} \mathrm{C}$, evaporator temperature $\mathrm{Te}=7^{\circ} \mathrm{C}$, and ambient temperature $\mathrm{Tc}=32.5^{\circ} \mathrm{C}$. This condition can meet a cooling load of $16 \mathrm{TR}$. In addition, the COP value of the system was found to be equal to 0.81 which is considered a good value for the COP of the absorption refrigeration system. To supply the system by the heat required to drive the absorption refrigeration system at optimum conditions an area of $84 \mathrm{~m}^{2}$ thermal photovoltaic collectors should be installed. Also, this system can be utilized for space heating due to a large amount of heat generated at higher efficiency

\section{Conclusions}

In this work, a mathematical model was developed for an absorption refrigeration cycle driven by a flat plat PV/T collector under Jordan climate conditions. The simulation study includes the thermal analysis, electrical analysis, and the absorption cycle performance. The results of this study show that the maximum solar radiation occurs in June and asymmetrical solar radiation in May and October. The thermal efficiency PV/T under the solar radiation range (500-1050) W/m $\mathrm{m}^{2}$ and wind speed $5 \mathrm{~m} / \mathrm{s}$ the PV/T collector was found to be in the range of (63.9 -72.5\%). At constant solar radiation of $500 \mathrm{w} / \mathrm{m}^{2}$ and a PV/T collector area of $1 \mathrm{~m}^{2}$ 
and a wind speed in that range of(1-12) $\mathrm{m} / \mathrm{s}$ the thermal efficiency was computed to be in the range of (44.6 - $63.6 \%)$. With wind speed of $5 \mathrm{~m} / \mathrm{s}$ and solar radiation of $500 \mathrm{~W} / \mathrm{m}^{2}, 1 \mathrm{~m}^{2}$ of PV/T collector are and flow rate range $(0.01-0.3) \mathrm{kg} / \mathrm{s} \mathrm{the} \mathrm{thermal}$ efficiency was found to be in the range of $(63.9-68.3 \%)$. The thermal efficiency remains constant after a flow rate equals 0.11 $\mathrm{kg} / \mathrm{s}$. The PV/T cells the efficiency decreases as the temperature as the ambient temperature increases.For the absorption refrigeration cycle as the condenser, temperature increases the minimum generator temperature needed to drive the cycle increases. At Jordan climate, the average maximum ambient temperature was found to be $31^{\circ} \mathrm{C}$ so at this condition the maximum $\mathrm{COP}$ for the cycle was equal 0.81 and the generator temperature was $80^{\circ} \mathrm{C}$.

\section{Nomenclature}

\begin{tabular}{|c|c|c|}
\hline $\mathrm{A}_{\mathrm{c}}$ & $=$ Collector area & {$\left[\mathrm{m}^{2}\right]$} \\
\hline $\mathrm{b}$ & $=$ Bond width & {$[\mathrm{m}]$} \\
\hline $\mathrm{C}_{\mathrm{b}}$ & $=$ Bond conductance & {$\left[\mathrm{W} / \mathrm{m}^{2} \mathrm{~K}\right]$} \\
\hline COP & $=$ Coefficient of performance & {$[-]$} \\
\hline $\mathrm{C}_{\mathrm{p}}$ & $=$ Specific heat at constant pressure & {$\left[\mathrm{kJ} / \mathrm{kg} .{ }^{\circ} \mathrm{C}\right]$} \\
\hline $\mathrm{D}_{\mathrm{i}}$ & $=$ Inner diameter of tube & {$[\mathrm{m}]$} \\
\hline $\mathrm{D}_{\mathrm{o}}$ & $=$ Outer diameter of tube & {$[\mathrm{m}]$} \\
\hline $\mathrm{El}$ & $=$ Heat exchanger effectiveness & {$[-]$} \\
\hline $\mathrm{F}$ & $=$ Fin efficiency factor & {$[-]$} \\
\hline$F^{\prime}$ & $=$ Collector efficiency factor & {$[-]$} \\
\hline FR & $=$ Heat removal factor & {$[--]$} \\
\hline $\mathrm{G}$ & $=$ Solar radiation & {$\left[\mathrm{W} / \mathrm{m}^{2}\right]$} \\
\hline hc,p_c & $=$ Convective heat transfer coefficient from cover to ambient & {$\left[\mathrm{W} / \mathrm{m}^{2} . \mathrm{K}\right]$} \\
\hline hw & $=$ Convective heat transfer coefficient from cover to ambient & {$\left[\mathrm{W} / \mathrm{m}^{2} . \mathrm{K}\right]$} \\
\hline hr,p_c & $=$ Radiation heat transfer coefficient from plat to cover & {$\left[\mathrm{W} / \mathrm{m}^{2} . \mathrm{K}\right]$} \\
\hline hr,c_a & $=$ Radiation heat transfer coefficient from cover to ambient & {$\left[\mathrm{W} / \mathrm{m}^{2} \mathrm{~K}\right]$} \\
\hline $\mathrm{k}$ & $=$ Thermal conductivity & {$[\mathrm{W} / \mathrm{m} . \mathrm{K}]$} \\
\hline $\mathrm{L}$ & $=$ Plate length & {$[\mathrm{m}]$} \\
\hline$\dot{\mathrm{m}}$ & $=$ Mass flow rate & {$[\mathrm{kg} / \mathrm{s}]$} \\
\hline $\mathrm{Nu}$ & $=$ Nusselt Number & {$[-]$} \\
\hline $\mathrm{Q}_{\mathrm{u}}$ & $=$ Useful thermal energy of $\mathrm{PV} / \mathrm{T}$ & [W] \\
\hline $\mathrm{Q}_{\mathrm{e}}$ & =Evaporator energy & {$[\mathrm{W}]$} \\
\hline $\mathrm{Q}_{\mathrm{g}}$ & $=$ Generator energy & [W] \\
\hline $\operatorname{Pr}$ & $=$ Prandtle Number & {$[-]$} \\
\hline $\mathrm{Re}$ & $=$ Reynold Number & {$[-]$} \\
\hline $\mathrm{S}$ & $=$ Solar radiation & {$\left[\mathrm{W} / \mathrm{m}^{2}\right]$} \\
\hline $\mathrm{T}_{\mathrm{a}}$ & $=$ Ambient temperature & {$[\mathrm{K})$} \\
\hline $\mathrm{T}_{\mathrm{i}}$ & $=$ Inlet fluid temperature & {$[\mathrm{K}]$} \\
\hline $\mathrm{T}_{\mathrm{o}}$ & $=$ Outlet fluid temperature & {$[\mathrm{K}]$} \\
\hline $\mathrm{T}_{\mathrm{ab}}$ & $=$ Absorber temperature & {$[\mathrm{K}]$} \\
\hline $\mathrm{T}_{\mathrm{co}}$ & $=$ Condenser temperature & {$[\mathrm{K}]$} \\
\hline $\mathrm{T}_{\mathrm{e}}$ & $=$ Evaporator temperature & {$[\mathrm{K}]$} \\
\hline $\mathrm{T}_{\mathrm{g}}$ & $=$ Generator temperature & {$[\mathrm{K}]$} \\
\hline $\mathrm{T}_{\mathrm{pv}}$ & $=\mathrm{PV}$ cells temperature & {$\left[{ }^{\circ} \mathrm{C}\right]$} \\
\hline $\mathrm{T}_{\mathrm{p}}$ & $=$ Plat temperature & {$[\mathrm{K}]$} \\
\hline $\mathrm{t}$ & $=$ Pipe thickness & {$[\mathrm{m}]$} \\
\hline $\mathrm{U}_{1}$ & $=$ Overall heat loss coefficient & {$\left[\mathrm{W} / \mathrm{m}^{2} \mathrm{~K}\right]$} \\
\hline $\mathrm{v}$ & $=$ Wind speed & {$[\mathrm{m} / \mathrm{s}]$} \\
\hline $\mathrm{Wp}$ & $=$ pump work & {$[\mathrm{W}]$} \\
\hline $\mathrm{X}$ & $=$ Concentration & {$[-]$} \\
\hline \multicolumn{3}{|c|}{ Greek Symbols } \\
\hline$\beta$ & $=$ Cell efficiency temperature factor Emissivity & {$[-]$} \\
\hline$\delta$ & $=$ Fin thickness & {$[\mathrm{m}]$} \\
\hline$\varepsilon$ & $=$ Emissivity & {$[-]$} \\
\hline$\eta_{\mathrm{o}}$ & $=\mathrm{PV}$ cell efficiency at standard conditions & {$[-]$} \\
\hline$\eta_{\mathrm{el}}$ & $=\mathrm{PV}$ cells electrical efficiency & {$[-]$} \\
\hline$\eta_{\text {th }}$ & $=\mathrm{PV} / \mathrm{T}$ thermal efficiency & {$[-]$} \\
\hline$\mu$ & $=$ Viscosity & [Pa.s] \\
\hline$\rho$ & $=$ Density & {$\left[\mathrm{kg} / \mathrm{m}^{3}\right]$} \\
\hline$\sigma$ & $=$ Stefan - Boltzmann constant & {$\left[\mathrm{W} / \mathrm{m}^{2} \mathrm{~K}^{4}\right]$} \\
\hline
\end{tabular}

\section{References}

Ammar A., K. Sopian, M. Alghoul, B. Elhub, and Elbrek A., "Performance study on photovoltaic/thermal solar-assisted heat pump system", Jour. of Therm. Analy. and Calor. 136, 79-87 (2019)

Assilzadeh F., S. A. Kalogirou, Y. Alia, and Sopianam K., "Simulation and optimization of a LiBr solar absorption cooling system with evacuated tube collectors", Renew. Energy, 30, 1143-1159 (2005)

Bhargava AK, Garg HP, and Agarwal R., "Study of a hybrid solar system-solar air heater combined with solar cells", ENERG CONVERS MANAGE; 31, 471-479 (1991)

Brinkworth B., Brinkworth and Sandberg M., "Design procedure for cooling ducts to minimize efficiency loss due to temperature rise in PV arrays", Sol. 
Energy, 80, 89-103 (2006)

Brown D., Dirks J., "Economic Sizing and Dispatch of Central Energy Plant Equipment at the Navy Medical Center, San Diego", Cogen.and Comp. Power J., 17, 21-36 (2002)

Cengel Y., Ghajar A., "Heat and mass transfer fundamental and applications", $4^{\text {th }}$ Edn., McGraw-Hill Higher Education, (2011).

Dai N., Xinyi X., Shuhong L., and Zheng Z. "Simulation of Hybrid Photovoltaic Solar Assisted Loop Heat Pipe/Heat Pump System", Appl. Sci., 7, 1-11 (2017)

Dubey S., and Tiwari G.,"Thermal modeling of a combined system of photovoltaic thermal (PV/T) solar water heater", Sol. Energy, 82, 602-612 (2008)

Dubey S. and Subiantoro A., "Numerical Study of Integrated Solar Photovoltaic-Thermal Module with a Refrigeration System for Air-Conditioning and Hot Water Production under the Tropical Climate Conditions of Singapore", Int J Air-Cond Refrig., 26, 1850021-10 (2018)

Duffie J. A. and William A., "Solar Engineering of Thermal Processes", $4^{\text {th }}$ Edn., John Wiley and Sons, Inc., (2013)

Fudholi A, Sopian K, Ruslan M., and Alghoul M., "Sulaiman MY "Review of solar dryers for agricultural and marine products", Renew Sustain Energy Rev., 14, 1-30 (2010)

Vokas G., N. Christandonis, and Skittides F., "Hybrid photovoltaic-thermal systems for domestic heating and cooling-A theoretical approach", Sol. Energy, 80, 607-615 (2006)

Chamberlain G., "Organic solar cells: A review", Sol Cells, 8, 47-83 (1983)

Gur M., Abraham K., Abraham D.,"Solar cooling with concentrating photovoltaic/thermal (CPVT) systems ”, Energy and Management, 47, 3368-3382 (2007)

Ibrahim A., Mohd Y., Ruslan M., Sohif Mat, and Kamaruzzaman S.,"Recent advances in flat plate photovoltaic/thermal (PV/T) solar collectors", RENEW SUST ENERG REV, 15, 352-365 (2011)

Jordan Meteorological Department (JMD), Solar data for Jordan (2011)

Kaushik S., Akhilesh A. "Energy and exergy analysis of single effect and series flow double effect water-lithium bromide absorption refrigeration systems", INT J REFRIG., 32, 1247-1258 (2009)

Kumar S., and Tiwari G., “An experimental study of hybrid photovoltaic thermal (PV/T)-active solar still”, Int J Energy Res. 32, 847-58 (2008)

Lasnier F and Ang T., Photovoltaic Engineering Handbook, Adam Higler (1990)

Leonardo M., Nabin S., Xichun L., Reddy K., Tapas K., "Opportunities and challenges in micro- and nano-technologies for concentrating photovoltaic cooling: A review", Renew Sust Energ Rev, 20, 595-610 (2013)

Mario P., Rosaria C., and Giovanni P., "Flexible Solar Cells", Chem Sus Chem, 1, 880-891 (2008)

Matuska T., "Performance and economic analysis of hybrid PVT collectors in solar DHW system", Energy Procedia, 48, 150-156 (2014)

Mittelman G, Kribus A, Mouchtar O, and Dayan A., "Water desalination with concentrating photovoltaic/thermal (CPVT) systems", Sol Energy,83, 1322-1334 (2009.

atlamwala T., Gadalla M., and Dincer I., "Performance assessment of an integrated PV/T and triple effect cooling system for hydrogen and cooling production”, Int J Hydrogen Energy., 36, 11282-11291 (2011)

Srikhirin Pongsid ,Satha Aphornratan, Supachart Chungpaibulpatana, A review of absorption refrigeration technologies, Renew Sust Energ Rev., 16, 343$372(2001)$

Tintai C., Jie J., Hanfeng H., Gang P., Wei H., and Keliang L., "Distributed dynamic modelling and experimental study of PV evaporator in a PV/T solarassisted heat pump", Int. Jour. Heat Mass Trans., 52, 1365-73 (2009

Tiwari G. Nayak S., Dubey S, Solanki S., and Singh R., "Performance analysis of a conventional PV/T mixed mode dryer under no load condition", Int Jou. Energy Res., 33, 919-930 (2009)

TWINSOLAR, http://www.grammer-solar.com/en/products/twinsolar/ index.shtml; 2010 (accessed 2012)

Tyagia V., Kaushika S., and Tyagib S., "Advancement in solar photovoltaic/thermal (PV/T) hybrid collector technology", Renew Sust Energ Rev, 16, 1383-1398 (2012) 